Egyptian J. Anim. Prod. (2012) 49(2):233-240

\title{
PROTECTIVE EFFECT OF SOME MEDICINAL PLANTS ON BLOOD PARAMETERS, KIDNEY AND LIVER FUNCTIONS AND HISTO- PATHOGICAL FEATURES OF KIDNEY IN RATS
}

\author{
M.I. Badr, H.H. Khalifa, A.A. Abd EI Hamid, M.H. Khalil, M.H. and A.F.M. El koatb \\ Department of Animal Production, (Animal Physiology), Faculty of Agriculture, Al-Azhar \\ University, Cairo, Egypt
}

\section{SUMMARY}

The study was undertaken in the animal house belonging to the Animal Production Department, Faculty of Agriculture, Al-Azhar University. Twenty four adult male albino rats with an average live body weight of $130 \mathrm{gm}$ were allocated to 4 equal groups (6 rats each): group 1 (G1) served as the control group and was orally given $1 \mathrm{ml}$ of distilled water, group 2 (G2) was orally given $1 \mathrm{ml}$ Cymbopogon proximus (CP, halfa barr) suspension, group 3 (G3) was orally given $1 \mathrm{ml}$ Ammi visnaga (AV, Khella) suspension and group 4 (G4) was orally given administrated $1 \mathrm{ml}$ Ambrosia maritime (AM, deamsissa) suspension. Feeding and drinking water were offered ad-libitum during the experimental period. Two experiments were carried out during hot season in summer (August and September, 2009). The first experiment was designed to investigate the effect of medicinal plants (CP, $A V$ and $A M)$ after 60 days from the start of the treatments on kidney function and histological structure. The second experiment was designed to test the effect of medicinal plants on diurnal variations of blood plasma parameters within each treatment at the end of the experiment. In the first experiment, blood samples were collected and kidney were studied,whereos in the second experiment, blood samples were collected in heparinized tubes three times daily from all animals within each group at $8 \mathrm{am}, 4 \mathrm{pm}$ and $12 \mathrm{pm}$.. The aim of the study was to investigate the effect of using Cymbopogon proximus (Halfa barr, CP), Ammi visnaga (Khella, AV) and Ambrosia maritime (Deamsissa, AM) on kidney structure and function of albino rats.

Results indicate that the kidney histopathological sections of the control and CP groups showed normal renal glomeruli and tubules. On the other renal section showed minimal degenerative changes in renal glomeruli in AV group with normal tubules and mild degenerative changes of renal glomeruli in the form of proeifuation of glomerular epithelium and mild atrophy in some glomeruli in AM group.Oral administration of medicinal plants had no significant effect on plasma creatinine, urea nitrogen, total protein, albumin, globulin, albumin /globulin, ALT, AST. Meanwhile, AV significantly increased plasma glucose to be higher than that in other groups.

It could be concluded that CP is safe to be used as an effective remedy for renal spasms and diabetes treatment without any side effects on kidney function. Also, it could be recommended that AV could be used for treatment of kidney stone but the duration of treatment have to be no longer than two weeks. Meanwhile, kidney function must be considered during any treatment with AM which is mainly used for its hypoglycemic effect.

Keywords: Rat, medicinal plants, blood, metabolities enzymes, kidney, liver, histopathology

\section{INTRODUCTION}

The vegetation on the earth is aperennial and renewable source of food and energy which is necessary for the survival of most organisms. Plants are the green factors of our planet; they convert carbon dioxide and water to carbohydrates; and nitrogen to amino acids. Besides food, plants are considered to be the nature's green pharmacy, which provide drugs to maintain the good health and to restore the failing health of humans. The medicinal arts had its origin when mankind first began to use remedial measures to get rid of their pains, sufferings and other illnesses, by using healing potions prepared from plants. Thus, from the tribal medicines and folk medicines, we have reached the modern era of sophisticated synthetically made drugs. The medicines of the ancient civilization and cultures were mostly associated with plants.

Mansour et al. (2002) reported that the administration of lupinus termis, $C P$ or Zygophyllum coccineum suspensions to the diabetic rats could restore plasma glucose, urea, creatinine, total protein and albumin to their normal levels after 4 weeks of treatment. They concluded that these herb suspensions are capable of ameliorating the impaired diabetic kidney function in addition to its hypoglycemic control. Al-Sayeda et al. (2002) showed that treatment with $C P$ suspensions restored the plasma glucose level in alloxan diabetic rats. They also showed that treatments with $C P$ 
suspensions resulted in improvements in plasma total lipids, triglyceride and total cholesterol.

Ibrahim et al. (2004a) showed that feeding $2 \% A V$ for 3 weeks had no changes in serum AST, cholesterol and total lipids, while feeding on $2 \% A V$ for 6 or 9 weeks increased serum AST, cholesterol and decreased serum total lipid. Jouad et al . (2002) revealed that the aqueous extract of $A V$ at $20 \mathrm{mg} / \mathrm{kg}$ significantly reduced blood glucose in normal rats 6 hours after a single oral administration and nine days after repeated oral administration. This hypoglycemic effect is more pronounced in streptozotocin diabetic rats.

Ahmed and Khater (2001) fond that when rats were treated with acetaminophen alone they developed significant hepato-cellular damage as was evident from a significant increased in the serum levels of AST, and ALT when compared with the controls. Pretreatment of rats with $A M$ extract at doses of 100 and 200 $\mathrm{mg} / \mathrm{kg}$ markedly reduced the elevated serum levels of these hepatospecific enzymes. They concluded that $A M$ seems to preserve the structural integrity of the hepato-cellular membranes as evident by the significant reduction in the acetaminophen induced rise in serum enzymes in rats. The reversal of increased serum enzymes in acetaminophen induced liver damage by $A M$ may be due to the prevention of leakage of the intracellular enzymes by its membrane stabilizing activity. Ibrahem et al . (2004b) tested the effects of aqueous and ethanolic extracts of $A M$ on the glucose level in streptozotocin induced diabetic rats. The extracts showed a highly significant hypoglycemic effect on the experimental animals, after 10 days. All the diabetic rats exhibited normal glucose level and AST, and ALT enzymes returned to normal values after treatment with Ambrosia marritime.

The objective of this study was to investigate the effect of $C P, A V$ and $A M$ administration on kidney structure and function of albino rats.

\section{MATERIALS AND METHODS}

The study was undertaken in Department of Animal Production, Faculty of Agriculture, AlAzhar University, Cairo.

\section{Experimental Animals:}

The albino rats used in this study were obtained from Egyptian Organization for Biological Products and Vaccines, Cairo, Egypt and raised in the animal house. Animals were housed in cages where the mean ambient temperature ranged from 27 and to $31^{\circ} \mathrm{C}$. The photoperiod was approximately a 12-hour light /dark cycle. The standard laboratory chow and tap water were provided ad libitum. All animals were healthy and clinically free from diseases.

\section{Experimental design:}

The following parts of three medicinal plants were used in the present study: whole plant of $A M$, bark of $C P$ and seed of $A V$. Plants were obtained from the local market in Cairopowders and were suspended in boiled distilled water (100 $\mathrm{g}$ of medicinal plant were added into $300 \mathrm{ml}$ boiled water).

The study included 24 adult male albino rats, with an average live body weight of $130 \mathrm{~g}$ (ranged from $110-150 \mathrm{~g}$ ). Animals were randomly divided into four equal groups (6 rats each), as the following: G1-Control group orally administered with $1 \mathrm{ml}$ distilled water/ animal/day. Whereas the other three groups G2,G3 and G4 were orally odministed with $1 \mathrm{ml} C P, A V$ and $A M$ suspension/animal/day (333 mg/100 g BW/day), respectively .Ad libitum feed and drinking water were offered.

Two experiments were oyecuted for two months in summer (August and September 2009). The first experiment was designed to investigate the effect of feeding medicinal plants ( $C P, A V$ and $A M)$ for 60 days. The second experiment was designed to test the effect of the plant extracts on diurnal variations of blood parameters within each treatment at the end of the experiment. In the first experiment, blood samples were collected and kidney sections were investigated meanwhile, in second experiment, blood samples were collected three times daily from the 6 animals from each group at 8 a.m., 4 p.m. and 12 p.m. At the end of the experiment, rats were sacrificed to obtain the kidneys. Immediately after extraction, the kidneys was immersed in formalin $10 \%$ for two days, then washed in water, dehydrated in ascending grade of ethyl alcohol and finally cleared by xylene and embedded in melted paraffin wax. The kidney block was sectioned at six-micron cut and stained by eosin and heamatoxylin according to Pearse (1968).

\section{Blood sampling and analyses:}

Blood samples were obtained from rats by withdrawing blood from the orbital venous plexuses using a capillary tube. Then centrifuged at $3000 \mathrm{rpm}$ for $15 \mathrm{~min}$ to obtain plasma which was thens transferred to Ependorff tubes and stored at $-20^{\circ} \mathrm{C}$ until subsequent analyses.

Plasma creatinine was measured by colorimetric method based on Murray (1984). Plasma urea-nitrogen concentration was determined by using enzymatic colorimetric 
method according to Tabacco et al. (1979). Plasma total protein was determined using colorimetric method according to Henry (1964). Plasma albumin was measured using Diamond Kits according to Dumas and Biggs (1972). Plasma globulin was calculated by subtraction of albumin from total protein. The glucose concentration was determined by glucose oxidase method (Trinder,1969). Plasma ALT was determined by using a colorimetric method according to Reitmena and frankel (1957). Plasma AST was determined by using a quantitative colorimetric method according to Henry (1974). Plasma total lipids was measured by colorimetric method based on the method of Zollner et al. (1962).

\section{Statistical analyses:}

Data were collected and statistically analyzed by the analysis of variance using ANOVA procedure of SAS program (SAS, 1996) at the 0.05 probability level. Duncan's Multiple Range Test $(\mathrm{P}=0.05)$ was used to test the effect of treetment (control, Cymbopogon proximus (Halfa barr), Ammi visnaga (Khella) and Ambrosia maritime (Deamsissa) at the end of the experiment as well as test the effect of diurnal variations within each group.

\section{RESULTS AND DISCUSSION}

\section{Histopathological changes of the kidney:}

The kidney strctur of the control and $C P$ groups showed normal renal glomeruli and tubules (Figs 1and 2). Renal fauture showed minimal degenerative changes in renal glomeruli in the $A V$ group with normal tubules and mild degenerative changes of renal glomeruli in the form of proeifuation of glomerular epithelium and mild atrophy in some glomeruli in the $A M$ group(Figs 3and 4). No side effects of $C P$ on kidney function have been reported in the literature which is in constancte with the present results. Consequently, $C P$ is safe to be used as an effective remedy for renal spasms (AbouShoer et al., 2011) and diabetes treatment. AlSayeda et al. (2002) and Mansour et al. (2002) found that suspension of $C P$ restored the plasma glucose of alloxan induced diabetic rats to the normal level due to increased insulin levels (Eskander and Won Jun, 1995).

Regarding the effect of $A M$ on renal histopathology, similar results had been reported by Abuelgasim et al. (2007) who found that oral administration of Ambrosia maritime ( $A M$ group) caused degeneration of the renal tubules. Also, Mansour et al. (2007) found few changes in renal tissues of rats treated with $A M$ extract. So, the effect of AM on kidney function must be considered during any treatment with AM which is mainly used in folk medicine for its hypoglycemic effect (Ibrahim et al., 2004b). Owing to the effect of $A V$. Vanachayangkul, et al. ( (2011) found that the histopathological examination of the kidneys revealed that oral administration of $A V$ extract for 14 days had no significant effect on kidney histopathology. However, it did significantly reduced the incidence of calcium oxalate $(\mathrm{CaOx})$ crystal deposition. In addition, $A V$ significantly increased urinary excretion of citrate along with a decrease of oxalate excretion. The main beneficial effects of $A V$ in human medicine is its use in kidney stone treatment. Tilgner (2000) reported that $A V$ is used in kidney stone treatment due to its strong antispasmodic action on the ureters thereby allowing the passage of kidney stones. Khan et al. (2001) revealed that the antilithiatic effect of $A V$ is mainly because of highly potent diuretic activity and amelioration of uraemia and hyperbilirubinemia by seeds of $A V$. The slight changes in kidney histopathology in $A V$ group in the present study may be due to the shoster duration of the treatment (two months) compared with 2 weeks as the in Vanachayangkul et al. (2011) study. So, it is recommended that $A V$ can be used for treatment of kidney stone but the duration of treatment should not be longer than two weeks.

\section{Blood plasma parameters:}

Table (1) shows that oral administration of medicinal plants had no significant effect on plasma creatinine, urea total protein, albumin, globulin, A/G ratio, ALT, AST. Meanwhile, $A V$ significantly increased plasma glucose to be higher than that in other groups which is in contradiction with previous results. Where, Jouad et al. (2002) revealed that administration with $A V$ aqueous extract at $20 \mathrm{mg} / \mathrm{kg}$ had a significant hypoglycemic effect in normal and streptozotocin diabetic rats. This contradiction may be due to the different doses used, duration of treatment between the present work and that in the literature. Also, it may be due to the inhibitory effect of $A V$ treatment on insulin secretion or to the effect of $A V$ on gluconeogensis causing the increase in plasma glucose and insignificant decrease in total lipids (Table 1). studies are needed to investigate the effect of dose and duration of $A V$ administration on plasma glucose. On the other hand, $A M$ treatment caused insignificant decrease in plasma glucose level (Table 1) which is in agreement with Ibrahem et al. (2004b) who found that the Ambrosia marritima extracts showed a highly significant hypoglycemic effect on the streptozotocin induced diabetic rats after ten days. The insignificant effect of $C P$ on plasma glucose is in contrast with the findings of Al Sayeda et al. 
(2002) and Mansour et al. (2002) who works on alloxan diabetic rats indicates that $C P$ has a hypoglycemic effect on diabetic rats only, while in normal rats $C P$ has no significant effect on plasma glucose. Similar conclusions had been reported by Ibrahim et al. (2004b) who found that the addition of $A M$ extract significantly decreased serum glucose in all of the streptozotocin diabetic rats, while, its hypoglycemic effect was not observed in normal rats. They concluded that the hypoglycemic effects may be exerted through the inhibition of glucose absorption, increase sensitivity of receptors to insulin, insulin as inhibiting effect, stimulation of $\beta$-cells of pancreas to secret insulin or stimulation of peripheral tissues uptake of glucose.

\section{Diurnal effect:}

Table (2) shows that although there was a significant diurnal variation in plasma parameters which differ in different groups but the mean plasma parameters level at different times in different groups were within the clinical normal range, except plasma glucose level indicating that these diurnal changes were clinically insignificant and no significant diurnal changes in kidney function had been occurred due to medicinal plants treatments. Plasma glucose was significantly higher at day time (at 8:00 am) than at night (at 12:00 pm in control, $C P$ and $A V$ groups and at 4:00 pm in $A M$ group) may be due to eating time and increasing activities during at 8:00 am. (Badr 2002).

\section{CONCLUSION}

Cymbopogon proximus (halfa barr) is safe to be used as an effective remedy for renal spasms and diabetes treatment without any adverse side effects on kidney function. Also, it is recommended that Ammi visnaga could be used for treatment of kidney stones but the duration of treatment should be no longer than two weeks. Meanwhile, kidney function must be considered during any treatment with Ambrosia maritime which is mainly used for its hypoglycemic effect.

\section{REFERENCES}

Abou-Shoer, M.I., H.M. Fathy and A.A. Omar, 2011. Extract-template modeling and pattern recognition in the assessment of Cymbopogon proximus. Am. J. Analytil. Chem., 2: 500-510.

Abuelgasim, A.I., A.O. Fatih Elrahman, and M. Galal, 2007. Toxicopathological effects of Ambrosia maritime L.,(Compositae) extracts in rats.Vet.Res., 1:71-75.
Ahmed, M. .B and M.R. Khater, 2001. Evaluation of the protective potential of Ambrosia marritima extract on acetamino phen-Einduced liver damage. J. Ethnopharamcol., 75: 169 - 174.

Al-Sayeda , A. N., A. M. Hamdy ,, M.I. Yousef and S.A. Sheweita, 2002. Alterations of lipid profile in plasma and liver of diabetic rats :Eeffect of hypoglycemic herbs. J.Environ. Sci. Health Part B-Pesticides, Food Contaminants, and Agriculatural Wastes ,.P37. (5): 475 - 484.

Badr, M.I., 2002. Effect of some medicinal plants on plasma glucose and insulin levels. M.SC. Thesis, Fac. Agric. Al-Azhar Univ. Cairo. Egypt., P 2.

Dumas B.T.and H.G.Biggs, 1972. Standard Methods of Clinical Chemistry.Vol.7 Academic Press . New York.USA., PP175.

Eskander ,E .F. and H. Won Jun. 1995. Hypoglycemic and hyperimslinems effects of some Egyptian herbs used for the treatment of diabetes mellitus (type 11) in rats. Egypt. J. Pharm. Sci., 36 :331-342.

Henry, J.B. 1974. Clinical Diagnosis and management by laboratory method W.B saunders Co. Philadelphia., 361.

Henry, R.J. 1964. Clinical Chemistry. Harper and Row Publishers ,NewYork .USA., PP 181.

Ibrahim, I.A., S. M. A. El Badwi and W. S. Abdel Gadir, 2004a . Susceptibility of Bovans chicks to low dietary levels of Ammi visnaga and Artemisia herba-alba . Vet. Human-Toxicol., 46: 67 - 69.

Ibrahem, Z.T. Z., A. A. Moustafa and E. M. Attia , 2004b. Effect of nitrogen and managanese foliar spray on growth, yield, active constituents in Ambrosia marritime and its herb extract on hyperglycemia in streptozotocin induced diabetic rats. Bull. Fac. Agric. Cairo Univ., 55: $569-586$.

Jouad, H., M. Maghrani and M. Eddouks, 2002. Hypoglycemic effect of aqueous extract of Ammi visnaga in normal and streptozotocin- induced diabetic rats. Journal-of-Herbal-Pharmacotherapy., 2: $19-29$.

Khan, Z.A., A.M. Assiri, H.M. Al-Afghani and T.M. Maghari, 2001. Inhibition of oxalate nephrolithiasis with Ammi visnaga (AiKhillah). Int. Urol. Nephrol., 33: 605-608.

Mansour , H. A., A.A Newairy., M.I. Yousef and S. A. Sheweita , 2002. Biochemical study on the effects of some Egyptian herbs in alloxan induced diabetic rats. .Toxicol.,170: 221 - 228.

Mansour, N.M., M.N. Tawfik ., T.R. Rahmy and A.E. Yaseen, 2007. Protective effect of Ambrosia maritima plant extract against renal alterations induced by Leiurus 
quinquestriatus Scorpion envenoming. Egyptian J. Natural Toxins., 4(2): 101 -130.

Murray ,R.L. 1984 .Clin .Chem The C.V. Mosby Co.Stouis.Toronto.Princeton.,12611266.

Pearse,A.G.E,1968.Histochemistry:Theoretical and Applied, $3^{\text {rd }}$ edition. Churchill Livingstone. New York.USA.,PP.613-658.

Reitmena, S. and S.Frankel, 1957. Am.J. clin Path. 25 - 56.

Tabacco, A., 1979. Clin Chem., 25: 336 - 337.
Tilgner, S. 2000. Herbal Transitions, Urinary Tract Health. A Botanical Newsletter for Health Care Practitioners, V . 2.

Trinder,P.1969.Ann Chin Biochem.,6 : 24 - 33.

Vanachayangkul, P.,N.Chow, S.R Khan and V. Butterweck, 2011. Prevention of renal crystal deposition by an extract of Ammi visnaga $L$. and its constituents khellin and visnagin in hyperoxaluric rats. Urol. Res., 39(3):189-195.

Zollner,N., K .Kirsch and Z. Ges, 1962 . Exp .Med .,V:135-545.

Table 1. The effect of medicinal plants on different plasma parameters

\begin{tabular}{|c|c|c|c|c|c|c|c|c|c|c|c|c|}
\hline \multirow[t]{2}{*}{ Parameter } & \multicolumn{3}{|c|}{ G1 } & \multicolumn{3}{|c|}{ G2 } & \multicolumn{3}{|c|}{ G3 } & \multicolumn{3}{|c|}{ G4 } \\
\hline & Mean & S.E & dt & Mean & S.E & dt & Mean & S.E & dt & Mean & S.E & dt \\
\hline Creatinine $\quad(\mathrm{mg} / \mathrm{dl})$ & 0.58 & 0.035 & $\mathbf{a}$ & 0.57 & 0.038 & $\mathbf{a}$ & 0.55 & 0.019 & $\mathbf{a}$ & 0.50 & 0.025 & $\mathbf{a}$ \\
\hline$(\mathrm{mg} / \mathrm{dl})$ & 49.83 & 2.040 & $\mathbf{a}$ & 45.47 & 1.929 & $\mathbf{a}$ & 43.71 & 2.037 & $\mathbf{a}$ & 45.01 & 1.954 & $\mathbf{a}$ \\
\hline Total protein $(g / d l)$ & 6.28 & 0.254 & $\mathbf{a}$ & 6.34 & 0.155 & $\mathbf{a}$ & 6.26 & 0.186 & $\mathbf{a}$ & 5.83 & 0.135 & $\mathbf{a}$ \\
\hline Albumin $\quad(g / d l)$ & 3.17 & 0.120 & $\mathbf{a}$ & 3.67 & 0.285 & $\mathbf{a}$ & 3.47 & 0.033 & $\mathbf{a}$ & 3.23 & 0.393 & $\mathbf{a}$ \\
\hline Globulin & 3.11 & 0.157 & $\mathbf{a}$ & 2.67 & 0.299 & $\mathbf{a}$ & 2.79 & 0.132 & $\mathbf{a}$ & 2.60 & 0.215 & $\mathbf{a}$ \\
\hline $\mathbf{A} / \mathbf{G}$ ratio & 1.01 & 0.529 & $\mathbf{a}$ & 1.37 & 0.180 & $\mathbf{a}$ & 1.24 & 0.176 & $\mathbf{a}$ & 1.24 & 0.416 & $\mathbf{a}$ \\
\hline Glucose & 104.71 & 5.521 & b & 105.19 & 7.669 & b & 125.54 & 6.133 & $\mathbf{a}$ & 93.11 & 6.305 & $\mathbf{b}$ \\
\hline ALT & 8.33 & 0.870 & $\mathbf{a}$ & 9.06 & 0.891 & $\mathbf{a}$ & 10.89 & 1.695 & $\mathbf{a}$ & 10.78 & 1.307 & $\mathbf{a}$ \\
\hline AST & 22.28 & 4.142 & $\mathbf{a}$ & 20.61 & 5.166 & $\mathbf{a}$ & 19.11 & 5.958 & $\mathbf{a}$ & 20.51 & 4.272 & $\mathbf{a}$ \\
\hline Total lipids (mg/dl) & 252.12 & 13.959 & $\mathbf{a}$ & 255.58 & 18.873 & $\mathbf{a}$ & 244.95 & 9.761 & $\mathbf{a}$ & 265.67 & 12.030 & $\mathbf{a}$ \\
\hline
\end{tabular}

S.E. $\quad=$ Standard error

dt : Duncan's Multiple Range Test between groups . Means within each row with similar letters are not significantly different at $\mathrm{p} \leq 0.05$.

G1 $=$ Control

G2=Cymbopogon proximus

G3=Ammi visnaga

G4=Ambrosia maritime 
Table 2. The effect of medicinal plants on plasma 60 days from the beginning of the experiment

\begin{tabular}{|c|c|c|c|c|c|c|c|c|c|c|c|c|c|}
\hline \multirow{2}{*}{ Parameters } & & \multicolumn{3}{|l|}{ G1 } & \multicolumn{3}{|l|}{ G2 } & \multicolumn{3}{|l|}{ G3 } & \multicolumn{3}{|l|}{ G4 } \\
\hline & & Mean & S.E & dt & Mean & S.E & dt & Mean & S.E & dt & Mean & S.E & dt \\
\hline \multirow{4}{*}{$\begin{array}{l}\text { Creatinine } \\
\text { (mg/dl) }\end{array}$} & 8:00am & 0.57 & 0.02 & $\mathbf{A B}$ & 0.57 & 0.03 & $\mathbf{A B}$ & 0.51 & 0.02 & B & 0.56 & 0.02 & $\mathbf{A}$ \\
\hline & 4:00pm & 0.62 & 0.08 & $\mathbf{A}$ & 0.61 & 0.08 & $\mathbf{A}$ & 0.54 & 0.04 & AB & 0.53 & 0.04 & $\mathbf{A B}$ \\
\hline & $12: 00 p m$ & 0.54 & 0.08 & B & 0.53 & 0.09 & B & 0.58 & 0.02 & A & 0.42 & 0.02 & B \\
\hline & 8:00am & 52.03 & 4.50 & $\mathbf{A}$ & 45.47 & 1.43 & $\mathbf{A B}$ & 40.90 & 3.33 & B & 45.43 & 3.08 & $\mathbf{A B}$ \\
\hline \multirow{3}{*}{$\begin{array}{l}\text { Urea } \\
(\mathrm{mg} / \mathrm{dl})\end{array}$} & $4: 00 \mathrm{pm}$ & 49.33 & 2.77 & $\mathbf{A B}$ & 40.87 & 1.28 & B & 41.57 & 4.24 & $\mathbf{A B}$ & 40.20 & 0.29 & B \\
\hline & 12:00pm & 48.13 & 4.24 & B & $\mathbf{5 0 . 0 7}$ & 4.45 & $\mathbf{A}$ & 48.66 & 1.48 & $\mathbf{A}$ & 49.40 & 3.87 & $\mathbf{A}$ \\
\hline & 8:00am & 6.60 & 0.21 & $\mathbf{A}$ & 6.43 & 0.26 & $\mathbf{A B}$ & 5.80 & 0.15 & B & 5.93 & 0.18 & $\mathbf{A B}$ \\
\hline \multirow{3}{*}{$\begin{array}{l}\text { Total } \\
\text { protein } \\
\text { (g/dl) }\end{array}$} & 4:00pm & 6.53 & 0.68 & $\mathbf{A}$ & 6.50 & 0.35 & $\mathbf{A}$ & 6.20 & 0.06 & $\mathbf{A B}$ & 6.06 & 0.32 & $\mathbf{A}$ \\
\hline & $12: 00 p m$ & 5.70 & 0.10 & B & 6.10 & 0.23 & B & 6.77 & 0.39 & $\mathbf{A}$ & 5.50 & 0.00 & B \\
\hline & 8:00am & 4.53 & 0.22 & $\mathbf{A}$ & 3.70 & 0.27 & B & 4.03 & 0.03 & $\mathbf{A B}$ & 4.13 & 0.23 & $\mathbf{A}$ \\
\hline \multirow{3}{*}{$\begin{array}{l}\text { Albumin } \\
\text { (g/dl) }\end{array}$} & 4:00pm & 4.46 & 0.44 & $\mathbf{A}$ & 4.40 & 0.46 & $\mathbf{A}$ & 3.90 & 0.15 & B & 3.76 & 0.32 & B \\
\hline & $12: 00 p m$ & 3.90 & 0.15 & B & 4.13 & 0.29 & AB & 4.57 & 0.07 & A & 3.67 & 0.32 & B \\
\hline & 8:00am & 2.07 & 0.41 & $\mathbf{A}$ & 2.73 & 0.33 & $\mathbf{A}$ & 1.77 & 0.15 & B & 1.80 & 0.27 & B \\
\hline \multirow{3}{*}{$\begin{array}{l}\text { Gobulin } \\
\text { (g/dl) }\end{array}$} & 4:00pm & 2.07 & 0.29 & $\mathbf{A}$ & 2.10 & 0.62 & $\mathbf{A B}$ & 2.30 & 0.20 & AB & 2.30 & 0.55 & $\mathbf{A}$ \\
\hline & 12:00pm & 1.80 & 0.12 & B & 1.97 & 0.47 & B & 2.20 & 0.06 & $\mathbf{A}$ & 1.83 & 0.32 & B \\
\hline & 8:00am & 2.18 & 0.53 & A & 1.35 & 0.18 & B & 2.27 & 0.18 & A & 2.29 & 0.42 & A \\
\hline \multirow{2}{*}{$\begin{array}{l}\text { A/G } \\
\text { ratio }\end{array}$} & $4: 00 \mathrm{pm}$ & 2.18 & 0.22 & B & 2.09 & 0.97 & $\mathbf{A}$ & 1.69 & 0.25 & B & 1.63 & 0.77 & B \\
\hline & 12:00pm & 2.16 & 0.21 & B & 2.09 & 0.46 & $\mathbf{A B}$ & 2.07 & 0.00 & B & 2.00 & 0.58 & $\mathbf{A B}$ \\
\hline \multirow{4}{*}{$\begin{array}{l}\text { Glucose } \\
\text { (mg/dl) }\end{array}$} & 8:00am & 120.60 & 5.55 & A & 129.45 & 5.44 & A & 134.58 & 13.30 & A & 108.10 & 9.72 & A \\
\hline & 4:00pm & 106.27 & 7.28 & AB & 106.23 & 4.03 & $\mathbf{A B}$ & 123.60 & 1.67 & B & 73.93 & 2.40 & B \\
\hline & $12: 00 p m$ & 87.27 & 1.53 & B & 79.90 & 6.73 & B & 118.40 & 14.26 & B & 97.30 & 8.48 & $\mathbf{A}$ \\
\hline & 8:00am & 8.67 & 2.33 & $\mathbf{A}$ & 8.67 & 2.05 & $\mathbf{A B}$ & 12.33 & 0.44 & $\mathbf{A}$ & 11.17 & 1.17 & $\mathbf{A B}$ \\
\hline \multirow{3}{*}{$\begin{array}{l}\text { ALT } \\
(\mathbf{u} / \mathbf{l})\end{array}$} & 4:00pm & 7.67 & 1.59 & B & 8.17 & 1.48 & B & 9.00 & 5.53 & B & 13.67 & 2.91 & $\mathbf{A}$ \\
\hline & 12:00pm & 8.67 & 0.88 & $\mathbf{A}$ & 10.33 & 1.36 & $\mathbf{A}$ & 11.33 & 8.08 & $\mathbf{A B}$ & 7.50 & 1.04 & B \\
\hline & 8:00am & 15.50 & 4.25 & B & 25.00 & 2.08 & $\mathbf{A B}$ & 13.50 & 4.75 & $\mathbf{A B}$ & 27.20 & 11.37 & $\mathbf{A}$ \\
\hline \multirow{3}{*}{$\begin{array}{l}\text { AST } \\
(\mathbf{u} / \mathbf{l})\end{array}$} & 4:00pm & 27.17 & 10.94 & $\mathbf{A}$ & 27.50 & 14.79 & $\mathbf{A}$ & 34.50 & 14.87 & A & 13.33 & 0.88 & B \\
\hline & $12: 00 p m$ & 24.17 & 5.60 & $\mathbf{A B}$ & 9.33 & 0.60 & B & 9.33 & 0.60 & B & 21.00 & 6.37 & $\mathbf{A B}$ \\
\hline & 8:00am & 298.17 & 20.58 & $\mathbf{A}$ & 245.60 & 13.28 & $\mathbf{A B}$ & 247.06 & 0.38 & $\mathbf{A B}$ & 302.50 & 18.12 & $\mathbf{A}$ \\
\hline \multirow{2}{*}{$\begin{array}{l}\text { Total } \\
\text { lipids } \\
\text { (mg/dl) }\end{array}$} & 4:00pm & 231.20 & 12.20 & $\mathbf{A B}$ & 233.73 & 28.02 & B & 212.77 & 4.79 & B & 244.80 & 19.60 & B \\
\hline & $12: 00 \mathrm{pm}$ & 227.00 & 13.08 & B & 287.40 & 50.18 & $\mathbf{A}$ & 275.03 & 12.15 & A & 249.70 & 0.69 & $\mathbf{A B}$ \\
\hline \multicolumn{14}{|c|}{ S.E. = Standard error } \\
\hline $\begin{aligned} G 1 & =\text { Control } \\
G 2 & =C y m b o\end{aligned}$ & on pro & & & & & & $f-1$ & Ituste & ne & & & & \\
\hline
\end{tabular}




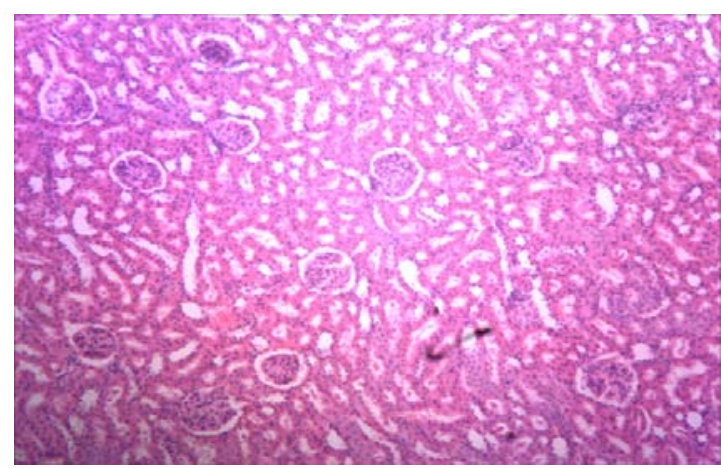

Fig. (2): Kidney structure in the Cymbopogon proximus group showing normal renal glomeruli and tubules (X100).

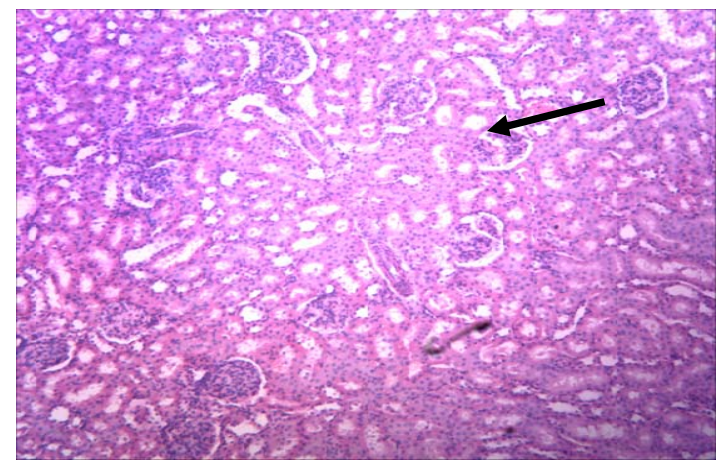

Fig. (4): Kidney structure in the Ambrosia marritima group showing mild atrophic changes of renal glomeruli (X100).
Fig. (1): Kidney structure in the control group showing normal renal glomeruli and tubules (X100).

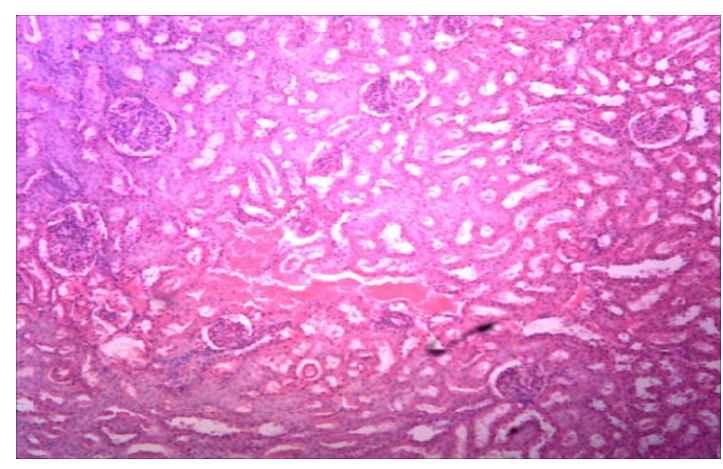

Fig. (3): Kidney structure in the Ammi visnaga group showing minimal degenerative changes of renal glomeruli and normal tubules (X100).

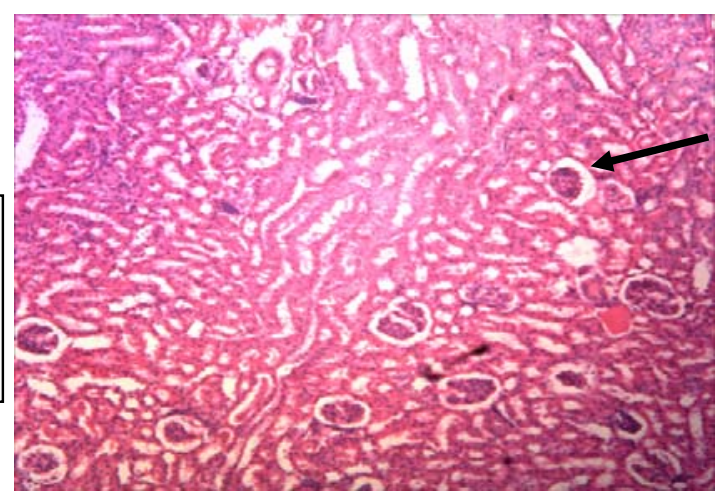


التاثيرالوقائى لبعض النباتات الطبيةعلى بعض مقاييس الدم ووظائف الكبا و الكلى وفحص امراض النسيج المميزة فى كلية الفئران النيان

مصطفى إسماعيل بدر سبيع، هثام حسين خليفة حسين، عبدالحميد عبد الله عبد الحميد، مدحت حسين خليل محمد، أحمد فوزى محمود القطب البعاع

قسم الاتتاج الحيوانس، كلية الزراعة، جامعة الأزهر، القاهره

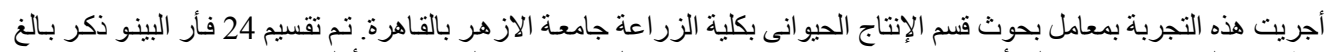

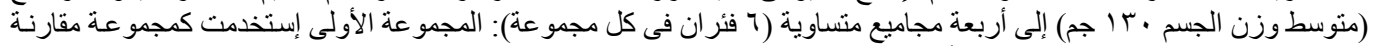

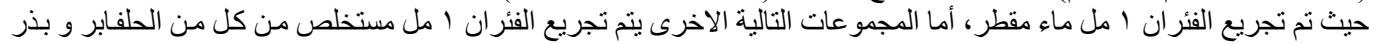

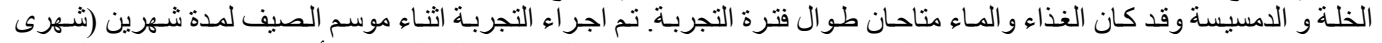

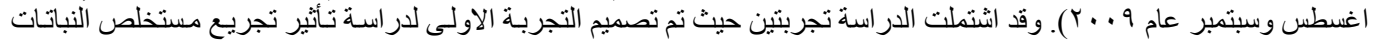

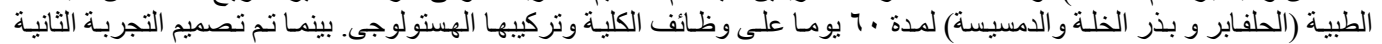

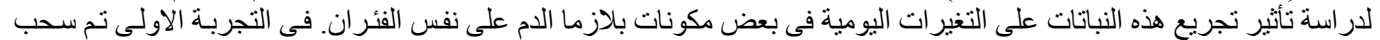

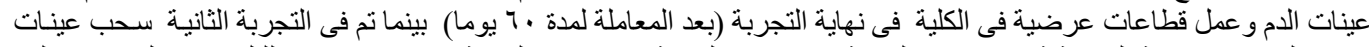

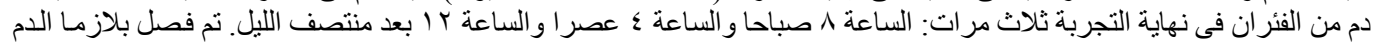

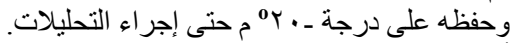

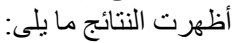

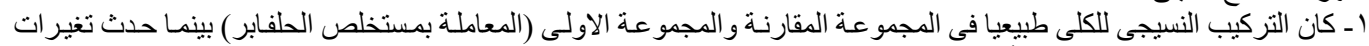

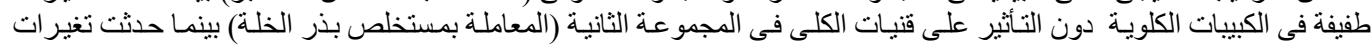

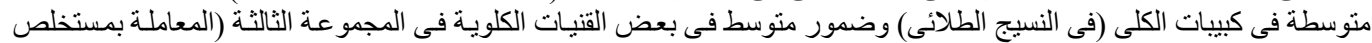
نبات الدمبيسة).

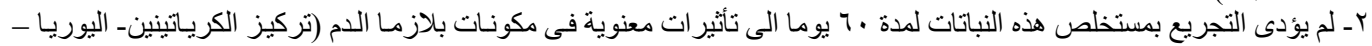

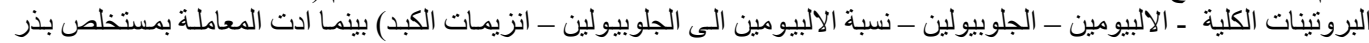
الخلة الى زيادة معنوية فى تركيز سكر الجلوكوز فى بلازما الدام.

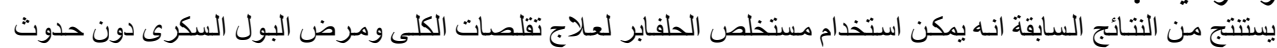

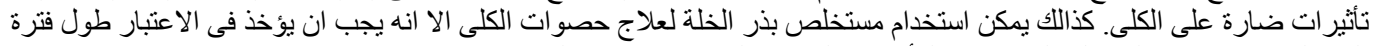

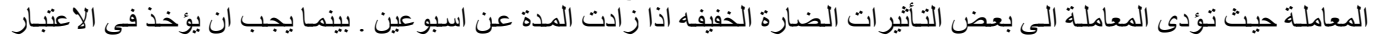

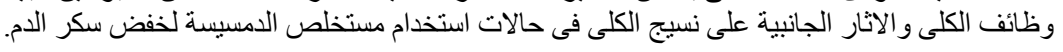

